\title{
Structural Soil and Water Conservation Practices in Farta District, North Western Ethiopia: An Investigation on Factors Influencing Continued Use
}

\author{
Adugnaw Birhanu $^{1^{*}}$ and Desalew Meseret ${ }^{2}$ \\ 1Department of Geography and Environmental Studies, Debre Tabor University, PO Box: 297, Debre Tabor, \\ Ethiopia.
}

${ }^{2}$ Department of Natural Resource Management, Debre Tabor University, PO Box 272, Debre Tabor, Ethiopia

\begin{tabular}{|c|c|}
\hline Abstract & Article Information \\
\hline \multirow{12}{*}{$\begin{array}{l}\text { Soil degradation is one of the most serious environmental problems in Ethiopia. The } \\
\text { Ethiopian highlands have been experiencing declining soil fertility and severe soil erosion } \\
\text { due to intensive farming on steep and fragile lands and other factors attributed to } \\
\text { population pressure. Although different soil and water conservation structures have } \\
\text { extensively been introduced over the past decades, sustained use of the measures was not } \\
\text { as expected. The limited success of those efforts highlights the need to better understand } \\
\text { the factors that influence sustainable use of structural soil and water conservation } \\
\text { measures. This study used logistic model to investigate the major factors influencing the } \\
\text { continued use of structural soil and water conservation measures in Farta district. Both } \\
\text { purposive and simple random sampling techniques were applied to select sample kebeles } \\
\text { and representative households respectively. Data collected from } 162 \text { sample households } \\
\text { were used to estimate the logistic model. The result shows that only } 47.2 \text { percent of the } \\
\text { respondents continually used the structural conservation measures and the remaining were } \\
\text { not due to different determinant factors, of which perception of farmers on erosion and } \\
\text { technology profitability was the major factor followed by institutional factors including } \\
\text { tenure security, extension contact, access to training and membership in local } \\
\text { organizations. Therefore, plan for intervention in soil conservation and sustainable use of } \\
\text { measures should recognize these heterogeneous conditions and farmers' preferences. }\end{array}$} & Article History: \\
\hline & Received : 15-09-2013 \\
\hline & : 22-12-2013 \\
\hline & Accepted : 24-12-2013 \\
\hline & Keywords: \\
\hline & Logistic Regression \\
\hline & Soil Erosion \\
\hline & Soil Conservation Structures \\
\hline & Continued Use \\
\hline & ${ }^{*}$ Corresponding Author: \\
\hline & Adugnaw Birhanu \\
\hline & \\
\hline
\end{tabular}

\section{INTRODUCTION}

Ethiopia is one of the countries in Sub-Saharan Africa. Its economy is mainly dependent on rain-fed agriculture (Bekele, 1998). The agricultural sector is the main source of employment for about 80 percent of the population. It also contributes to a very large proportion of the country's GDP (MoFED, 2002). The Ethiopian farmer, who on average cultivates one hectare of food crops and keeps some livestock, is nowadays dependent on natural conditions and cannot tolerate further deterioration of soil productivity (Sonneveld and Keyzer, 2003). Soil and water conservation in Ethiopia is therefore not only closely related to the improvement and conservation of ecological environment, but also to the sustainable development of its agricultural sector and its economy at large (Abera, 2003). In Ethiopia, efforts towards this conservation goal were started since the mid-1970s and 80s (Wogayehu and Drake, 2001; Bekele and Holden, 1998). Since then, different soil conserving technologies with a varied approach has been underway. The focus was on the highland areas of the country where the problem is threatening and food deficit is prevalent. The conservation efforts were mainly undertaken through Food-for-Work
(FFW) program benefits (Abera, 2003). Despite these huge efforts in the past, it has been demonstrated that some farmers who put up the erosion controlling structures with incentives of Food-for-Work (FFW) destroyed the structures in the absence of the incentives (Bekele and Holden, 1998).

In many parts of Ethiopia several kilometers of structural soil and water conservation measures were constructed on croplands. However, reports indicated that these conservation structures have not been sustainably used by the farmers (Fisum, et al, 2002; Betru, 2002; Yeraswork, 2000). Although the failure of soil conservation intervention can have many causes, it resulted mainly from the fact that planners and implementing agencies ignored local level biophysical and socio-economic realities. This is essential in planning effective and efficient land management technologies that will be accepted by farmers after empirical understanding of diverse socio-economic variables affecting their conservation decision (Woldeamlak, 2002). 


\section{Adugnaw Birhanu and Desalew Meseret}

In view of this, it would be worthwhile to evaluate the factors influencing continued use of soil and water conservation technologies. Therefore, the main objective of the study is to assess major factors influencing continued use of structural soil and water conservation measures in Farta District, North-Western Ethiopia. Within the framework of this objective, the following question guided this study: What are the major factors influencing continued use of structural soil and water conservation measures in the study area?

\section{MATERIALS AND METHODS}

\section{Description of Study Area}

This research is undertaken in Farta district of South Gonder Zone, Amhara regional state, Ethiopia. The study area is located at $660 \mathrm{kms}$ North-West of Addis Ababa, capital city of Ethiopia and lies between the coordinates of $11^{\circ} 32^{\prime}$ to $12^{\circ} 03^{\prime} \mathrm{N}$ latitude and $37^{\circ} 31^{\prime}$ to $38^{\circ} 43^{\prime} \mathrm{E}$ longitude with an estimated area of $1118 \mathrm{~km}^{2}$.

The entire area of the study district has a topography characterized by extremely high relief in the upper watershed of Blue Nile River system. Over 70 percent of the land area is characterized by gently inclined hills and gully landscape. This makes the area highly exposed to serious soil erosion problem (Abera, 2003). The altitude of the study area varies between 1900 and 4035 meter above mean sea level with topography of gentle to undulating (Yitbarek, 2007). In terms of climatic condition the study district has average annual minimum, maximum and mean temperatures respectively $9.7,22,15.5^{\circ} \mathrm{C}$. The rainfall pattern is uni-modal, stretching from May to September. The annual rainfall ranges between 1097 and $1954 \mathrm{~mm}$ with a long term average of $1448 \mathrm{~mm}$ (Yitbarek, 2007). According to the Wereda Agriculture Office Annual Report (2006) 65 percent of land is cultivated, 10 percent is grazing, 8 percent settlement and 16 percent others. The district is known with mixed farming zone where crop and livestock enterprises are interacting in the system. Livestock plays a significant role in the system. It is the major source of draft power and it also serves as a source food and source of cash (Yitbarek, 2007; Abera, 2003).

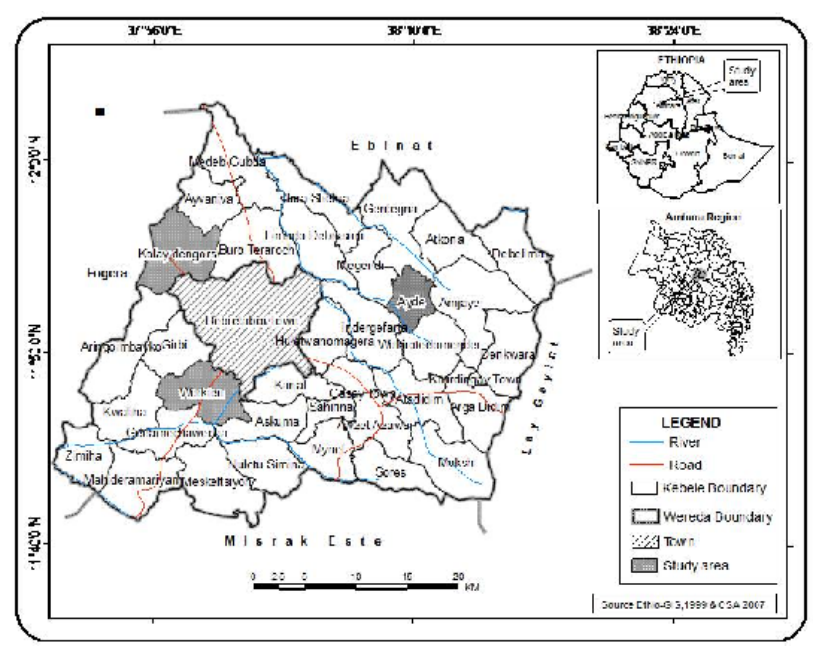

Figure 1: Location map of Farta District, Ethiopia.

\section{Sample Size and Sampling Techniques}

The district is purposefully selected due to the fact that in the area very high attempt of soil and water

\section{Sci. Technol. Arts Res. J., Oct-Dec 2013, 2(4): 114-121}

conservation structures has been undertaken and continued use of these structures is not satisfactory. Once the district is selected, three kebele were selected from the complete list of 37 kebele using a simple random sampling procedure. Then, lists of households in each kebele were obtained from the respective kebele offices. With the lists, a systematic random sampling procedure was used to select a total of 162 sample households. In cases where a selected household happened to be away from home for a long time or was unwilling to be interviewed, randomly selected substitutes were included. In all, one hundred and sixty two sample farmers were selected 64(39.5\%), 57(35.2\%) and 41(25.3\%) from Kolay Dengores,Workien and Ayde kebele respectively.

\section{Data Collection and Analysis}

The data collected for this study involved both primary and secondary sources. The questionnaire was piloted by administering it to selected respondents from nearby kebele of the district (21 household heads) for further modification on its content, ordering of questions and clarity. Formal interview, focused group discussions and filed observation were used to gather deep data which were difficult to collect through structured questionnaire as well as to triangulate the information gathered through structured questionnaire. Six focused group discussions, two sessions in each sample kebele (having 4-6 participants) were held. Transect walk across different plots was also used in order to obtain all the necessary physical information about the area and to characterize and understand biophysical and terrain features such as topography, erosion status, land uses, soil type, slope characteristics, structural soil and water conservation practices and other field conditions. More than these, secondary sources of data were collected from published and unpublished materials such as journals, Agricultural reports, discussion papers, and statistical abstracts collected from zonal, district and kebele level offices of agriculture.

For the analysis of the collected data descriptive and econometric methods were employed. The descriptive techniques such as frequency, mean, ratio and percentage were computed for different variables. With regard to econometric analysis, a logistic regression model was utilized to investigate the influence of different independent variables on continued use of structural soil and water conservation practices. The data analysis was carried out using the SPSS version 15 software packages.

\section{Model Specification}

For this study, a model that reflects the determinants of continued use of structural soil and water conservation measures on any particular farm was required. Different literature on soil and water conservation investments was assessed to select appropriate model. Logit and probit models are popular statistical techniques in which the probability of a dichotomous outcome (such as continued use or non-continued use) is related to a set of explanatory variables that are hypothesized to influence the outcome (Neupane et al., 2002). However, Pindyck and Rubinfeld (1981: P. 287) acknowledged logistic probability function as computationally easier to use than the other types. That is why logistic regression model was used for this study. 
Adugnaw Birhanu and Desalew Meseret

$$
P_{i}=F\left(\alpha+\beta X_{i}\right)=1 / 1+e^{-\left(\alpha+\beta X_{i}\right)}
$$

Where: Subscript $i$ denotes the $i$-th observation in the sample; $\mathrm{Pi}$ is the probability that an individual will make a certain choice given $\mathrm{X}_{\mathrm{i}}$; $\mathrm{e}$ is the base of natural logarithms and approximately equal to $2.718 ; X_{i}$ is a vector of exogenous; variables $\alpha$ and $\beta$ are parameters of the model, $\beta_{1}, \beta_{2} \ldots \ldots, \beta_{k}$ are the coefficients associated with each explanatory variables $X_{1}, X 2, \ldots, X_{n}$. The above function can be rewritten as:

$$
\ln [P /(1-P)]=\beta_{0}+\beta_{1} X_{1}+\beta_{2} X_{2}+\ldots+\beta_{k} X_{k}
$$

Where: $\quad P /(1-P)$ is the odds (likelihoods); $\beta_{0}$ is the intercept; $\beta 1, \beta_{2} \ldots$ and $\beta_{k}$ are coefficients of the associated independent variables of $X_{1}, X_{2} \ldots$ and $X k$.. The effect of the independent variables (e.g., $\beta_{1}$ ) is interpreted as the odds (likelihoods) of the outcome increases or decreases by a factor of $e^{\beta 1}$. The quantity $e^{\beta 1}$ is called the odds ratio. The odds ratio is a measure of association between the independent and the dependent variables. If
Sci. Technol. Arts Res. J., Oct-Dec 2013, 2(4): 114-121

$\beta<0$, the likelihood of the outcome decreases; if $\beta>0$, the likelihood of the outcome increases and if $\beta=0$, the independent variable does not have any effect on the likelihood of the outcome. It should be noted that the estimated coefficients reflect the effect of individual explanatory variables on its $\log$ of odds $\{\ln [P /(1-P)]\}$. The positive coefficient means that the log odds increase as the corresponding independent variable increases and the inverse is true for negative coefficients (Neupane et al., 2002).

\section{Working Hypotheses and Variable Specification}

Studies made on farmers' decision on continued use of soil conservation structures and related theories indicated that wide range of social, demographic, socioeconomic, physical and institutional factors influence continued use. Hence, based on findings of these studies and experience, potential explanatory variables that can influence decision of farmers are identified and they are presented below (table 1).

\begin{tabular}{|c|c|c|}
\hline \multicolumn{2}{|l|}{ Variable name } & \multirow{3}{*}{ 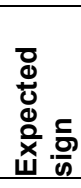 } \\
\hline \multicolumn{2}{|c|}{ Dependent Variable } & \\
\hline CONUSE & $\begin{array}{l}\text { Continued use of soil and water conservation measures; } 1 \text { if a farmer is } \\
\text { practicing SWC measures continuously, } 0 \text { otherwise }\end{array}$ & \\
\hline \multicolumn{3}{|c|}{$\begin{array}{l}\text { Explanatory variables } \\
\text { Social factors }\end{array}$} \\
\hline $\mathrm{X} 1=\mathrm{AGE}$ & Age of the household head in years & \pm \\
\hline X2=HHSIZE & Number of people in the household & \pm \\
\hline $\mathrm{X} 3=\mathrm{EDUCTION}$ & Literacy of the household head; 1 if literate and 0 otherwise & + \\
\hline$X 4=S E X$ & Gender of the household head; 1 if male and 0 otherwise & + \\
\hline \multicolumn{3}{|c|}{ Institutional factors } \\
\hline X5=TENURE & $\begin{array}{l}\text { Security of land tenure: } 1 \text { if the farmer considered that he/she will be able } \\
\text { to use the plot at least during his /her lifetime, } 0 \text { otherwise }\end{array}$ & + \\
\hline X6=MEMBSHIP & $\begin{array}{l}\text { Membership in local organizations; } 1 \text { if a farmer is a member and } 0 \\
\text { otherwise }\end{array}$ & - \\
\hline X7=TRAIN & $\begin{array}{l}\text { Training about soil conservation received by the farmer; } 1 \text { if a farmer got } \\
\text { training and } 0 \text { otherwise }\end{array}$ & + \\
\hline X8=EXTENSION & Extension contact: 1 if the farmer gets extension contact, 0 Otherwise & \\
\hline \multicolumn{3}{|l|}{ Physical Factors } \\
\hline X9=FRMSIZE & Size of the farm, in hectares & \pm \\
\hline $\mathrm{X} 10=\mathrm{DISTANC}$ & Average distance of a plot from homestead, in minutes & - \\
\hline X11=SLOP & Slope of the plot as perceived by farmer; 1 if steep and 0 otherwise & \pm \\
\hline X12=SOILFERT & Soil fertility status of the plot; 1 if fertile, 0 otherwise & + \\
\hline \multicolumn{3}{|c|}{ Economic Factors } \\
\hline X13=OFFARM & $\begin{array}{l}\text { Engagement in off-farm employment; } 1 \text { if a farmer has off-farm employment } \\
\text { and } 0 \text { otherwise }\end{array}$ & + \\
\hline X14=LANDUS & Land use type; 1 if for cultivation, 0 otherwise & + \\
\hline X15=LIVESTOC & Livestock holding of the household (numbers) & + \\
\hline \multicolumn{3}{|c|}{ Attitudinal Factors } \\
\hline X16=PERERO & $\begin{array}{l}\text { Perception of soil erosion as a problem; } 1 \text { if farmer had perceived erosion } \\
\text { as a problem, } 0 \text { otherwise }\end{array}$ & + \\
\hline X17=PERPROF & Perceived profitability of the structure; 1 if perceived profitable, 0 otherwise & + \\
\hline
\end{tabular}

Table 1: The summary of definition and measurement of variables used in the model.

\section{RESULTS AND DISCUSSION}

\section{Descriptive Results}

As presented in Table 3, the data on personal demographic characteristics revealed that the age of the farmers ranged from 21-30, 31-40, 41-50 years accounting for 21.6, 26.6, 40.1 percent of the populations respectively, while 11.7 percent were above 50 years. Also, it can be seen that 58 and 42 percent of the respondents were males and females respectively. The implication of this to farmers lies in the availability of workforce for farm activities. In the case of literacy, 56.8 percent of the farmers had no formal education, 26.6 percent attended primary school while 16.6 percent had the opportunity of attaining secondary school education.

The family size in the study area ranges from 1 to 12 persons with an average of 6.2 persons per household. 


\section{Adugnaw Birhanu and Desalew Meseret}

So, farm households have a large number of children who are less than 15 years. The number of children ranges from 2 to 12 with an average of about 4 . If we consider family size focusing on economically active groups i.e. members whose age is between 15 and 64, on average there are about 2 economically active members per a family. In general household size of 1-5, 6-10 and above 10 accounts $59.3,25.3$ and 15.4 percent of the respondents respectively.

Table 2: Frequency distribution of respondents according to their personal demographic characteristics $(n=162)$.

\begin{tabular}{lcc}
\hline Variable category & Frequency & Percentage \\
\hline Age & 35 & 21.6 \\
$21-30$ & 43 & 26.6 \\
$31-40$ & 65 & 40.1 \\
$41-50$ & 19 & 11.7 \\
Above 50 & $\mathbf{1 6 2}$ & $\mathbf{1 0 0}$ \\
Total & & \\
\hline Gender & 94 & 58 \\
Male & 68 & 42 \\
Female & 162 & 100 \\
Total & & \\
Education & 92 & 56.8 \\
No formal education & 43 & 26.6 \\
Primary education & 27 & 16.6 \\
Secondary education & $\mathbf{1 6 2}$ & $\mathbf{1 0 0}$ \\
Total & & \\
\hline House hold size & 96 & 59.3 \\
1-5 & 41 & 25.3 \\
6-10 & 25 & 15.4 \\
Above 10 & $\mathbf{1 6 2}$ & $\mathbf{1 0 0}$ \\
Total & & \\
\hline
\end{tabular}

In 1994 a new constitution has been enacted in Ethiopia. In this proclamation farmers have been given the right to use their land indefinitely, but selling or mortgaging of land is still prohibited and land was subjected to redistributions with the main objective of equity and reduction of landlessness. In the Amhara Regional State, where this study was undertaken, land redistribution has been a very common observable fact. Particularly, in the study area, respondents revealed that they passed through different redistributions since the previous regime. They indicated the recent one undertaken in 1997 and 1998. The survey result showed that almost all of the sample households have been affected by this redistribution. Respondents were also asked whether they perceive a risk of loss of their plot of land in the future through redistribution. As indicate on table 4 out of 162 respondents 59.9 percent of the respondents anticipate the occurrence of future redistribution, which may affect their holding, while 40.1 percent of respondents indicated that due to certificate of land provided to them, they feel secured from redistribution of their land to land less people.

Regarding training provided to farmers about soil and water conservation, 25.3 percent of respondents obtained frequent training service on soil and water conservation organized by government and non-government organizations. However 74.7 percent of respondents obtain training service rarely.

Effort has been made to know how many households in the sample embraced in the current extension program.

\section{Sci. Technol. Arts Res. J., Oct-Dec 2013, 2(4): 114-121}

Farmers' were asked about the number of times they meet the extension agent and 34 percent reported that they meet the local Development Agent (DA) frequently once in month. But 66 percent of the farmers indicated that they meet the DA rare in month.

Table 3: Institutional factors that determine continued use of SWC measures.

\begin{tabular}{lcc}
\hline \multicolumn{1}{c}{ Variable category } & Frequency & Percentage \\
\hline Tenure system & & \\
Secured & 97 & 59.9 \\
Insecure & 65 & 40.1 \\
Total & $\mathbf{1 6 2}$ & $\mathbf{1 0 0}$ \\
\hline Training service obtained & & \\
Frequent & 41 & 25.3 \\
Rare & 121 & 74.7 \\
Total & $\mathbf{1 6 2}$ & $\mathbf{1 0 0}$ \\
\hline Extension service obtained & & \\
Frequent & 55 & 34 \\
Rare & 107 & 66 \\
Total & $\mathbf{1 6 2}$ & $\mathbf{1 0 0}$ \\
\hline
\end{tabular}

As in most of the highlands of the country, the landholding of farmers in the study area is very small. The per capita landholding in the study area is 0.14 ha. There is significant variation in the size of landholding among households. As depicted on table 5 minimum and maximum size of landholding were 0.25 and 2.5 ha, the average being 1.05 ha. The Majority of farmers (40.1\%) cultivate less than 1 ha of land. Households cultivating more than 1 ha accounted for only $26.6 \%$. Farmers having larger farm size are not interested to invest on conservation structures. Yet, once smallholders perceive the problem very well, they invest more on maintaining conservation structures to retain in the original state.

Farmers having land far from their residence accounted $53.7 \%$ and those farmers that have farming lands accounted $46.3 \%$ of respondents. Usually Farmers having land far from their residence do not give visit to their cultivation field except during harvesting and planting season. During slack season, livestock roam on the field freely and destroy bunds. Hence, farmlands situated far from residence suffer from destruction of conservation structures and enhanced erosion.

The soil fertility condition of cultivated plots is an important factor of farmers' decisions on the continued use of soil and water conservation practices. Farmers with poor soils or plot with low and medium fertility (72.9\%) are more involved in conservation work than those who have fertile land to improve the level of soil fertility and the productivity of the land at the plot level. However, farmers which have very fertile land $(27.1 \%)$ possibly do not see the negative effects of erosion on their plots in the short term.

The large portion concentrated in moderately sloping areas $(62.1 \%)$ while, $24.1 \%$ of farmers cultivating moderately sloping fields retained conservation structures in their original state. This is because on moderately sloping areas following steep and long slopes, the problem of soil erosion is severe due to runoff from up lands and farmers constructed in response to this problem. 
Adugnaw Birhanu and Desalew Meseret

Table 4: Physical factors that determine continued use of SWC measures

\begin{tabular}{lcc}
\hline \multicolumn{1}{c}{ Variable category } & Frequency & Percentage \\
\hline Farm size in hectare & & \\
$<0.5$ & 35 & 21.6 \\
$0.5-1$ & 65 & 40.1 \\
$>1$ & 43 & 26.6 \\
Total & 162 & 100 \\
\hline Farm distance from & & \\
home (in minute) & & \\
Far & 87 & 53.7 \\
Near & 75 & 46.3 \\
Total & 162 & 100 \\
\hline Soil fertility & & \\
Low & 77 & 47.5 \\
Medium & 41 & 25.4 \\
High & 26 & 16 \\
Very High & 18 & 11.1 \\
Total & 162 & 100 \\
\hline Slope & & \\
Gentle & 22 & 13.6 \\
Moderate & 39 & 24.1 \\
Steep & 101 & 62.3 \\
Total & 162 & $\mathbf{1 0 0}$ \\
\hline
\end{tabular}

As shown in table 6, majority of farmers $(71.6 \%)$ involve in off-farm activities. On the other hand, only $28.4 \%$ do not involve in activities that are different from agriculture. Livestock holding of farmers was divided into groups to analyze the response of farmers towards soil conservation structures. The percentage of farmers that destroyed conservation structures completely increased with increasing livestock holding. On the contrary, the percentage of farmers that destroyed structures selectively decreased tremendously from households with lower livestock holding to households with higher livestock holding. The majority of farmers $(41.3 \%)$ had the livestock in the range of $2.2-2.9$ and only $12.3 \%$ had the livestock with range of $>4.6$ measured in tropical livestock unit (TLU)

Table 5: Economic factors that determine continued use of SWC measures.

\begin{tabular}{lcc}
\hline \multicolumn{1}{c}{ Variable category } & Frequency & Percentage \\
\hline $\begin{array}{l}\text { Participation in off-farm } \\
\text { activity }\end{array}$ & & \\
Participated & 116 & 71.6 \\
Not participated & 46 & 28.4 \\
Total & $\mathbf{1 6 2}$ & $\mathbf{1 0 0}$ \\
\hline Land use pattern & & \\
Cultivation & 107 & 66 \\
Grazing & 34 & 21 \\
Forest & 21 & 13 \\
Total & $\mathbf{1 6 2}$ & $\mathbf{1 0 0}$ \\
\hline Livestock holding(TLU) & & \\
0-2.1 & 46 & 28.4 \\
2.2-2.9 & 67 & 41.3 \\
3.0-4.6 & 29 & 18 \\
>4.6 & 20 & 12.3 \\
Total & $\mathbf{1 6 2}$ & $\mathbf{1 0 0}$ \\
\hline
\end{tabular}

As can be seen from Table 7 , only about $5 \%$ of farmers indicated that there is no erosion problem on their farm land. The remaining $26 \%, 35 \%$ and $34 \%$ of farmers respectively perceived that there is at least low level of
Sci. Technol. Arts Res. J., Oct-Dec 2013, 2(4): 114-121

soil erosion, moderate erosion and severe erosion problem on their cultivated land.

Farmers' continued use of the introduced conservation structures showed interesting difference with differences in the perception of the effectiveness of introduced conservation structures in arresting soil erosion. Farmers indicated $(59.9 \%)$ that introduced conservation structures are as effective conservation structures. On the contrary, $40.1 \%$ of farmers' perceive soil and water conservation structures were not more effective measures and made decision to destroy conservation measures.

Table 6: Attitudinal factors that determine continued use of SWC measures.

\begin{tabular}{lcc}
\hline Variable category & Frequency & Percentage \\
\hline Perception of erosion & & \\
No erosion & 11 & 5 \\
Low Erosion & 43 & 26 \\
Moderate Erosion & 57 & 35 \\
Severe Erosion & 51 & 34 \\
Total & $\mathbf{1 6 2}$ & $\mathbf{1 0 0}$ \\
\hline Perception of SWC & & \\
profitability & & \\
Profitable & 97 & 59.9 \\
Not profitable & 65 & 40.1 \\
Total & $\mathbf{1 6 2}$ & $\mathbf{1 0 0}$ \\
\hline
\end{tabular}

\section{Empirical Findings}

Logistic regression model was used to analyze determinants of farmers to use structural soil and water conservation measures continuously. The variable continued use was used as a binary dependent variable (CONUSE) taking a value 1 indicating the farmer continually use the structures and 0 otherwise. The regression analysis was first performed for the three sample kebeles separately. However, except minor changes in the coefficient $\beta$ and the odds ratio, the determinant variables turned out to be similar. Therefore, the analysis was done for the whole sample households. The regression results are based on the 162 samples. The model results confirm that discontinues use of structural conservation measures was determined by the interaction of several factors. The success of the overall prediction by the regression model indicate that the variables sufficiently influence the farmers to decide on use of structural SWC measures, and there is a strong association between the decision and the group of the explanatory variables $\left(R^{2}=0.312\right)$. A positive estimated coefficient in the model implies continuous use of conservation measures with increased in the value of the explanatory variable. Whereas negative estimated coefficient in the model implies discontinuous use of conservation measures with increase in the value of the explanatory variable.

The logistic regression result shows that age and sex of the household head, family size, distance of the plot from the house, level of soil fertility, livestock size and offfarm income were found to influence continued use of structures while slope of the plot, extension contact, land tenure, educational level of the household head, perception of the household head on soil erosion problem and profitability of the structure are significant and positively correlated with continued use behavior. 


\section{Adugnaw Birhanu and Desalew Meseret}

The soil fertility condition of cultivated plots is an important determinant of farmers' investment in conservation practices. Our results show that soil fertility condition (SOILFERT) has a negative effect on continued use of the structures; farmers cultivating fertile plots noncontinually using the structures. This is contrary to expectations that farmers invest more on fertile plots in order to maximize production.

Lapar and Pandey (1999) in the Philippines found the slope of a plot to be one of the factors significantly influencing the continued use of structural conservation measures. Their results suggest that a farmer who has a field with steeper slope is more likely to continually use structures. Bekele and Holden (1998) and Berhanu and Swinton (2003) have also found similar result. Alemu (1999) found negative relationship between slope and continued use of conservation structures. He argued the returns from investment on steep sloped plots might be low, hence less apply of conservation structures on such plots. However, the result of Aklilu, (2006) indicates that farmers were encouraged to continue to use the structures perhaps due to effectiveness of the measure in erosion control on steep slopes. This suggests that targeting the structures on steep plots might induce sustained use of the measure. Consistent to this result, in our study, slope of a plot (SLOP) has been found statistically significant and positively correlated with continued use of structures. The implication is that the farmer who has a plot with steep slope is more likely to understand soil erosion problem and apply conservation structures than the farmer who has flat sloped plot.

As anticipated, farmers' perception of soil erosion problem (PERERO) has a positive and significant influence on continued use of structural soil and water conservation measures. The implication is that a farmer who feels that his/her farmlands are prone to soil erosion is more likely to continuously use physical soil and water conservation measures than those who do not perceive the problem of soil erosion. If the other variables remain the same, the farmer who perceive the problem of soil erosion is more likely to continuously use measures at a factor of 31.9 (odds ratio).

Farmers' perception of the actual profitability of SWC technology (PERPRO) was considered to be crucial for soil conservation undertakings and was hypothesized to influence their decision to sustainably apply conservation structures. This indicates that farmers who found the technology profitable retained it. Therefore, to ensure continued use, the conservation structures must be profitable to the farmer in the long run. Farmers who are non-continued users of the structures complain about yield losses due to pest infestation associated with the structures rather than effectiveness of the measure in erosion control. Farmers are very curious about the yield effect of the technology since the structures take up productive land and maintenance is often labour intensive and costly (Shiferaw and Holden, 1998). In our model, this variable found to be positively and significantly correlated with continued use behavior which is consistent with the result of Abera (2003).

The family size per household (HHSIZE) has negative effect on continued use decision of conservation
Sci. Technol. Arts Res. J., Oct-Dec 2013, 2(4): 114-121

structures. The result implies that households with large family size are not likely to continue using the structures. This is so because households with larger family size are likely to face food shortage. As a result, they try to maximize short-term benefits and would be less interested in soil conservation measures whose benefits can be reaped in the long run. Bekele and Drake (2003) and Bekele and Holden (1998) also found similar results. They noted that in a family with a greater number of mouths to feed, competition arises for labor between food generating off-farm activities, like daily labor, and less attention will be given for SWC activities.

The size of farm land/plot (FRMSIZE) was found to be positively associated with continued use of conservation structures and statistically insignificant. The positive coefficient implies that farmers with relatively larger holdings had higher probability to sustainably apply conservation technologies. This can be attributed to the fact that conservation structures occupy part of the scarce productive land and farmers with larger farm size can afford retaining structures compared to those with relatively lower farm size. The result is inconsistent with the finding of Pender and Kerr (1998) and Ervin and Ervin (1982) who reported a negative relationship between size of holdings and the probability of continued use of soil conserving structures. The studies explained this might be due to the labor-intensive nature of constructing soil conservation structure.

Consistent with our expectation, the coefficient of distance of a plot from homestead (DISTANC) was found to be negative. It implies that farmers with plots that are far from residential area had lower probability of sustainably using soil conservation structures. This can be attributed to the fact that farmers give more attention to nearby plots and the care given to distant plots is low. Therefore, the greater distance of a plot from homestead the lower attention will be given to continued use of conservation structures. This result is in line with Alemu's (1999) findings in Oromia Region of Ethiopia. He found that participation in soil conservation investment is negatively and significantly related to the physical distance of plots from the homestead. Another study conducted in northern Ethiopia also confirmed this result (Berhanu and Swinton, 2003). The result indicates that the distance of plots from the homestead affect negatively farmers' propensity to practice structural soil and water conservation.

The positive and significant correlation of contact with extension agents (EXTENTION) in this study implies that farmers having contacts with extension agents tend to understand the problem of soil erosion and the benefits of conservation measures and they are more likely to continually use conservation structures. The result is inconsistent with the finding of Aklilu (2006) in Beressa watershed, highlands of Ethiopia, who reported that discussions with extension staff in the area reveal that agricultural extension is more focused on crops and livestock production than on SWC.

Unexpectedly, the engagement of farmers in off farm activities (OFFARM) was found to influence continued use of conservation structures negatively. The implication is that farmers who involve in off-farm income generating 


\section{Adugnaw Birhanu and Desalew Meseret}

activities are far from the farming plots and likely to put less effort in maintenance and hence on retention of conservation structures. More than this, most of off-farm income is generated in the winter season which is also suitable time for farmers to undertake construction and maintenance of soil conservation activities. Hence, it appears that off-farm activities compete for the labor resource the farmer uses for conservation and maintenance of conservation structures. Alemu (1999), Gould et al. (1989) and Mbaga-Semgalawe and Folmer (2000) have also found that the probability of continual use of soil conservation structures decreases with increasing farmer's involvement in off-farm income generating activities. This may be due to the fact that farmers who involve more in off-farm employment have less commitment to the farm and hence, they do not view the economic impacts of soil erosion as being large enough to justify undertaking soil conservation

Table 7: Logistic model for continued use of SWC measures in Farta District.

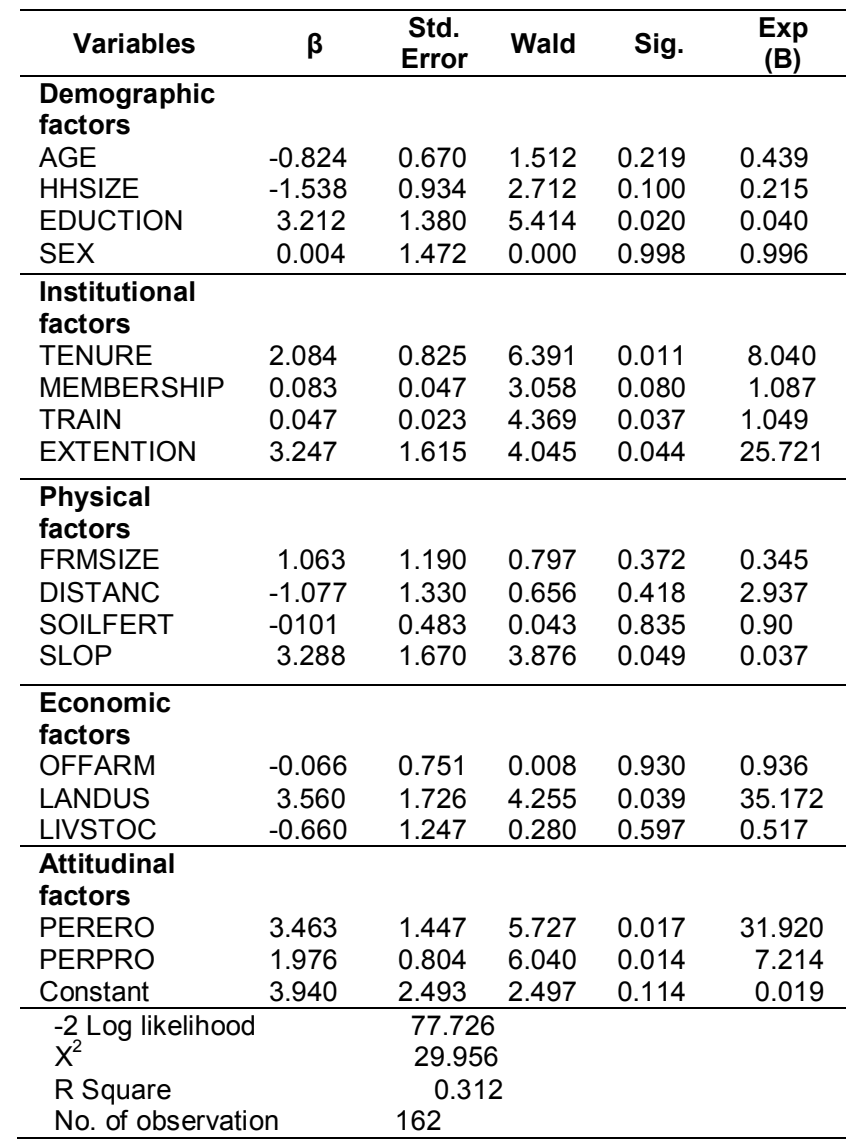

As expected, farmers' expectation of future security of the land (TENURE) influenced the decision of farmers on continued use of conservation structures positively and significantly. This positive attitude towards the security of land is associated with the land certificate distributed to the farmers to ensure the land to be their own. This result is supported by the property right literature that states secured land tenure gives incentives to farmers for applying and continue using land improving investments on their plots (Heltberg, 2001; and Abera, 2003). Contrary to this findings, the study conducted by Benin and Pender (2002) reported that the previous frequent redistribution of

\section{Sci. Technol. Arts Res. J., Oct-Dec 2013, 2(4): 114-121}

land, especially in Amhara Region, hinder the security of land because farmers anticipate similar redistribution of land to occur in the future. As a result the perceived risk of loss of land in the future was negatively associated with farmers' decision to retain introduced conservation structures.

Membership of the farmer in any organizations (MEMBERSHIP) and access to training (TRAIN) about conservation technologies are found to be positively and significantly associated with a continued use of conservation structures. This was mainly due to access of information in both cases. Generally, the result shows that attitudinal factors, i.e. perception of farmers on soil erosion problem and profitability of the technology significantly affected the decision of farmers to use structural SWC measures continuously or discontinuously followed by institutional factors, whereas, demographic, economic and biophysical factors are found to be less determinant.

\section{CONCLUSIONS}

This study attempted to identify important factors, which influence sustainable use of physical soil conservation measures in Northern Highlands of Ethiopia, Farta District. The empirical results show that the major factors influencing continued use of physical soil conservation measures in the study area are: slope of the plot, extension contact, land tenure, educational level of the household head, perception on soil erosion problem and profitability. An important implication of the results presented in this paper is that any intervention in soil conservation should recognize the heterogeneity in household characteristics, land holding, institutional patterns and technology-specific traits. It is critical that sustainable use of soil conservation measures critically depends on their suitability to the local ecology and the farming systems. Increase farmers' perception of soil erosion problem through the provision of knowledge and demonstration is also found to be far important. Therefore, to sustain structural soil water conservation, scientific knowledge should be coupled with indigenous knowledge to facilitate their dissemination and ensure their continuity.

\section{ACKNOWLEDGEMENTS}

First and foremost, the authors would like to thank Debre Tabor University for covering the full cost of the study. The authors would also thank staff of Department of Geography and Environmental Studies for their indispensable support and encouragement from Proposal development to completion of the research. Our sincere gratitude and thanks to Prof. Makonnen Asefa for his insightful guidance in our academic career and in this research.

\section{REFERENCES}

Abera Birhanu (2003). Factors influencing the adoption of soil conservation practices in north-western Ethiopia. M.Sc. Thesis, Institute of Rural development, University of Göttingen, Germany.

Aklilu Amsalu and De Graaff, J. (2006). Determinants of adoption and continued use of stone terrace for soil and water conservation in the Ethiopian highland watershed. Ecological Economics 61(3): 294-302. 


\section{Adugnaw Birhanu and Desalew Meseret}

Alemu, T. (1999). Land tenure and soil conservation: evidence from Ethiopia, PhD Thesis, Department of Economics, University of Gothenburg, Sweden.

Bekele Shiferaw (1998). Peasant Agriculture and Sustainable land use in Ethiopia. Economic Analysis of Constraints and Incentives for Soil Conservation. Agricultural University of Norway. Dissertation no: 1998:1.

Bekele Wogayehu. and Drake, L. (2003). Soil and water conservation decision behavior of subsistence farmers in the Eastern Highlands of Ethiopia: a case study of the Hunde Lafto area. Ecological Economics 46(3): 437-451.

Bekele Shiferaw and Holden, S.T. (1998). Resource degradation and adoption of land conservation technologies in the Ethiopian Highlands: A case study in Andit Tid, North Shewa. Agricultural Economics 18(3): 233-47.

Benin, S., Pender, J. (2002). Impacts of land redistribution on land management and productivity in the Ethiopian Highlands. Socio-economic and Policy Research Working Paper 43. ILRI, Addis Ababa, Ethiopia.

Berhanu, G., Swinton, S.M. (2003). Investment in soil conservation in Northern Ethiopia: The role of land tenure and public programs. Research in Agricultural and Applied Economics retrieved from http://purl.umn.edu/11749.

Betru, N. (2002). Soil and Water conservation program in Amhara National Regional State. Paper presented at a Conference on Natural Resources Degradation and Environmental Protection in the Amhara National Regional State held from July 24-26, 2002, Bahir Dar, Ethiopia.

Ervin, C.A., Ervin, E.D. (1982). Factors affecting the use of soil conservation practices: Hypotheses, evidence, and policy implications. Land Economics 58(3): $277-$ 292.

Fisum Hagos, Pender J., and Nega G. (2002). Land Degradation and Strategies for Sustainable Management in Ethiopian Highlands: Tigray Region (second edition) Socio-economic and Policy Research Working Paper 25. ILRI. Nairobi, Kenya.

Gould, B.W., Saupe, W.E., Klemme, R.M. (1989). Conservation tillage: The role of farm and operator characteristics and the perception of soil erosion. Land Economics 65(2):167-182.
Sci. Technol. Arts Res. J., Oct-Dec 2013, 2(4): 114-121

Heltberg, R. 2001. Property Rights and Natural Resource Management in the Developing Countries. Journal of Economic Surveys 16(2): 189-214.

Lapar, M.L.A., Pandey, S. (1999). Adoption of soil conservation: The case of the Philippine uplands. Agricultural Economics 21(3): 241-56.

Mbaga-Semgalawe, Z., Folmer, H. (2000). Household adoption behavior of improved soil conservation: The case of the North Pare and West Usambara Mountains of Tanzania. Land Use Policy 17(4): 321-36

MoFED, (2002). Ethiopia: Sustainable Development and Poverty Reduction Program. Addis Ababa, Ethiopia.

Neupane, R.P., Sharma, K.R., Thapa, G.B. (2002). Adoption of agroforestry in the hills of Nepal: A logistic regression analysis. Agricultural Systems 72(3):177196.

Pender, J., Kerr, J. (1998). Determinants of farmers' indigenous soil and water conservation investments in semi-arid India. Agricultural Economics 19(1-2): 113125.

Pindyck, R.S., Rubinfeld, D. L. (1981). Econometric models and economic forecasts. McGraw-Hill, London.

Sonneveld, B. G. J. S. and Keyzer M. A., (2003). Land under pressure: soil conservation concerns and opportunities for Ethiopia. Land Degradation and Development 14(1): 5-23.

Wogayehu Bekele and Drake, L. (2002). Adoption of soil and water conservation measures by subsistence farmers in the Eastern Ethiopia. Presented at the 17th World Congress of Soil Science, Bangkok, Thailand.

Woldeamlak Bewket (2002). Land Cover Dynamics since the 1950s in Chemoga watershed, Blue Nile Basin, Ethiopia. Mountain Research and Development 22(3): 263-269

Yeraswork Admasie (1988). Impact and sustainability study of WFP Assisted Project ETH 2488/II Rehabilitation of Forest, Grazing and Agricultural Lands. Addis Ababa. WFP.

Yitbare Tibebe (2007). Economic valuation of gully rehabilitation, a case study at Farta wereda, South Gonder. M.Sc. thesis. Addis Ababa University, Ethiopia. 